\title{
Correction to: Anaphora and negation
}

\author{
Karen S. Lewis ${ }^{1}$
}

Published online: 26 October 2020

(c) Springer Nature B.V. 2020

\section{Correction to: Philosophical Studies https://doi.org/10.1007/s11098-020-01489-w}

The original html version of this article was published with several errors. Footnote 8 was missing. The text of the footnotes to examples appeared as part of the example instead of as a footnote. This affected: fn. 1 , fn. 5 , fn. 6 , fn. 7 , fn. 15 (14 in the original html numbering), fn. 16 (15 in the original html numbering), fn. 38 (37 in the original html numbering), fn. 42 (41 in the original html numbering). The LaTeX code appeared instead of equations on some browsers. Example (51) was missing from the text and the syntactic tree from fn. 39 appeared in its place. The original article has been corrected.

Publisher's Note Springer Nature remains neutral with regard to jurisdictional claims in published maps and institutional affiliations.

The original article can be found online at https://doi.org/10.1007/s11098-020-01489-w.

Karen S. Lewis

klewis@barnard.edu

1 Department of Philosophy, Barnard College, Columbia University, Milbank Hall, 3009

Broadway, New York, NY 10027, USA 